\title{
Kiraz Üretimi Yapan İşletmelerin Makine ve Ekipman Alımlarının Desteklenmesi Programından (MEADP) Yararlanma Eğiliminin Belirlenmesi: İzmir-Kemalpaşa İlçesi Örneği*
}

Determining The Investment Perceptions of The Cherry Growing Farms Within Support Scheme For The Purchase of Agricultural Machines And Equipment (SSPME): A Case of Izmir-Kemalpasa District

\section{Belma DOĞAN ÖZ ${ }^{1^{*}}$, Gamze SANER ${ }^{2}$}

\section{Özet}

$\mathrm{Bu}$ araştırmada İzmir İli Kemalpaşa ilçesinde kiraz üretimi yapan işletmelerin "Kırsal Kalkınma Yatırımlarının Desteklenmesi Programı"nın (KKYDP) alt programı olan "Makine ve Ekipman Alımlarının Desteklenmesi Programı" (MEADP) yatırım desteğinden yararlanma eğilimlerini etkileyen faktörler belirlenmiş ve bu desteğin devamlılığı değerlendirilmiştir. İşletmelerin sosyo-ekonomik özellikleri işletme büyüklük grupları ve MEADP desteğinden yararlanan-yararlanmayan gruplamaya göre verilmiştir. Araştırmanın verileri 2015 üretim yılına ilişkin olup, bu destekten yararlanan 65, yararlanmayan 52 kiraz işletmesi olmak üzere toplam 117 işletmeden anket yoluyla elde edilmiştir.

Çalışmada kullanılan Logit modelin sonuçlarına göre; üreticilerin ilgili programdan yararlanma durumu üzerine, üreticinin eğitim süresi, kiraz üretimindeki deneyim süresi, Kemalpaşa Kiraz Üreticileri Birliğine üye olup olmama durumu, kiraz yetiştiriciliğinde uzmanlaşma durumu ve brüt kar gibi değişkenlerin pozitif etkisi olurken, üretici yaşının ise negatif etkisinin istatistiksel olarak anlamlı olduğu belirlenmiştir. Sonuç olarak bu destekten yararlanan işletmelerin makine-ekipman alt yapısının güçlenmesi ile birlikte iş yükünün azaldığı ortaya çıkmıştır. 2015 yılı sonrasında da makine ve ekipmanların bir kısmının desteklenmeye devam ettiği belirlenmiştir.

2007 yılında başlatılan Makine Ekipman Alımlarının Desteklenmesi Programı (MEADP) kapsamında 2014 yılına kadar 51 çeşit makine-ekipmandan oluşan toplam 270.044 adet makine ekipman alımı desteklenmiş ve bu makineekipmanlara toplam 1.212.225.834 TL hibe desteği verilmiştir. MEADP kapsamında desteklenen makine ve ekipman sayısı İzmir ilinde 2803 adet Kemalpaşa İlçesinde ise 245 adet olarak belirlenmiştir. İzmir ilinde 513 adet ve Kemalpaşa ilçesinde ise 96 adet ile en çok desteklenen makine-ekipmanın pülverizatör olduğu belirlenmiştir. Programın devamlılığı; üreticinin uygun fiyata, teknolojisi ileri çeşitli makine ekipmana sahip olarak, kaliteli ürün elde etmesi, tarımsal üretimini, gelirlerini böylece refahının artırılması açısından büyük önem taşımaktadır.

Anahtar Kelimeler: Kırsal Kalkınma, Tarımsal Yatırımlar, Kiraz, İzmir, Yatırım Destekleri

\footnotetext{
1*Sorumlu Yazar/Corresponding Author Belma DOGAN ÖZ ${ }^{1}$ Ege Universitesi Ziraat Fakültesi Tarım Ekonomisi Bölümü, Bornova. İzmir E-mail: belmadogan@hotmail.com, (D) OrcID: 0000-0003-1766-0016

${ }^{2}$ Gamze SANER Ege Üniversitesi Ziraat Fakültesi Tarım Ekonomisi Bölümü, Bornova, İzmir E-mail: gamzesaner@gmail.com (D) OrcID: 0000-0002-2897-9543 Atıf/Citation: Doğan Öz, B., Saner G. Kiraz Üretimi Yapan İşletmelerin Makine ve Ekipman Alımlarının Desteklenmesi Programından (MEADP) Yararlanma Eğiliminin Belirlenmesi: İzmir-Kemalpaşa İlçesi Örneği. Tekirdağ Ziraat Fakültesi Dergisi, 18 (1), 1-9.

*Bu çalışma Yüksek Lisans tezinden özetlenmiştir.

CBu çalışma Tekirdağ Namık Kemal Üniversitesi tarafından Creative Commons Lisansı (https://creativecommons.org/licenses/by-nc/4.0/)

kapsamında yayınlanmıştır. Tekirdağ 2021
} 


\begin{abstract}
In this research, It is determined the utilization conditions of investments for cherry growing farms within "Support Scheme for the Purchase of Agricultural Machines and Equipment," (SSPME) which is a subprogram of "Rural Development Investment Support Program" (RDISP) in Kemalpaşa district of Izmir and determined the factors affecting the investment utilization perceptions of the cherry growing farms. Socio-economic aspects of the cherry growing farms are grouped by the size of the enterprises and the utilization or non-utilization of the SSPME. The research data belongs to the production year 2015, using survey from 117 farms; 65 of which use the support and 52 of them did not use the support.

According to the Logit Model results, the education level of the producer, producer's experience of the cherry producing process, producer's membership status of the Kemalpaşa Cherry Producers Union, specialization of cherry producing and gross profit have positive effects also age of producer has a negative effect on producers' use of that support. As a result, it has been determined that the farms which have benefited from this support decreased the workload with the strengthening of the machine equipment infrastructure. It has been determined that some of the machinery and equipment continue to be supported after 2015 .

Within the scope of the Program for Support Scheme for the Purchase of Agricultural Machines and Equipment (SSPME) initiated in 2007, a total of 270,044 machine equipment purchases, consisting of 51 kinds of machine and equipments, were supported until 2014 and a total of 1.212.225.834 TL was granted to these machinery and equipment. The number of machines and equipment supported within the scope of SSPME was determined as 2803 in İzmir and 245 in Kemalpaşa District. In Izmir with the number of 513, and 96 in Kemalpaşa district, atomiser is the most widely used machine-equipment. Continuity of the program is matter great importance for the producer to obtain high quality products at an affordable price by having various advanced technology equipment and to increase agricultural production, income and welfare.
\end{abstract}

Keywords: Rural Development, Agricultural Investments, Cherry, Izmir, Investment Supports 


\section{Giriş}

Kiraz, dünyada yetiştiriciliği ve ticareti yapılan en önemli meyve türlerinden birisidir. Türkiye dünya kiraz üretiminde 2018 yılında 639564 ton ile birinci sırada yer almıştır. Türkiye’yi sırasıyla Amerika (312 430 ton), Özbekistan (172 035 ton), Şili (155 935 ton) ve İran (137 268 ton) izlemektedir (FAO, 2018). Türkiye 2019 y1lı itibariyle 183 milyon dolarlık kiraz ihracatında \%5.9'luk pay ile dünyada dördüncü sırada yer almaktadır (TradeMap, 2019). Türkiye'den ihraç edilen kiraz çeşitlerinin \%95'lik kısmını '0900 Ziraat' kiraz çeşidi oluşturmaktadır (Soysal, 2018). 2019 yılı itibariyle kiraz üretiminde Konya ili 68.213 ton ile birinci sirada yer alırken, İzmir ili 66,36 ton ile ikinci sırada yer almaktadır. Kemalpaşa ilçesi ise 42.99 ton ile İzmir ili kiraz üretiminin \%64.78'ini oluşturmaktadır (TUIK, 2019).

Türkiye'de kırsal alanlar ekonomik ve sosyal denge içerisinde önemli bir yere sahiptir. Kırsal alanlara yönelik geliştirilen kalkınma projeleri ve tarımsal desteklemelerle kırsal kesimi geliştirerek buradaki nüfusun ekonomik yönden kalkındırılması amaçlanmaktadır (Beycan, 2009). Kırsal kalkınma programları aracılığıyla kırsal alana yapılacak yatırımlar kentlere yönelen göçün ortaya çıkardığı çarpık kentleşmenin önüne geçebilecek ve oluşabilecek diğer sorunları da bir ölçüde engelleyebilecektir (Demirbük, 2013). Ancak kırsal alanlarda gelir ve istihdam arttırıcı unsurları oluşturmak kısa sürede çözülebilecek bir süreç değildir. Öncelikle yapılması gereken kırsal alanların dinamosu olan tarım sektörünü canlandırmak olmalıdır (Asoğlu, 2015). Tarım sektörüne hareket kazandırmak için klasik tarım ürünlerini desteklemenin yanında tarımsal ürünlerin işlenmesi, pazarlanması ve satışına olanak sağlayan tarıma dayalı sanayi kollarının desteklenmesi ayrıca tarımsal üretim tekniklerinin modernizasyonu büyük önem taşımaktadır. Bu konuda gereken adımlar atıldığı takdirde kırsal alanlarda yeni istihdam alanları oluşabilecek ve olası kırdan kente göç olgusu da azaltılabilecektir. Türkiye'de tarıma dayalı sanayinin desteklenmesi ve tarımsal üretimde modernizasyon konusunda en önemli gelişmelerden birisi Gıda, Tarım ve Hayvancılık Bakanlığı tarafından 2006 yılından bu yana uygulamada olan Kırsal Kalkınma Yatırımlarının Desteklenmesi Programı (KKYDP)'dır (Asoğlu ve ark., 2016).

Kırsal Kalkınma Yatırımlarının Desteklenmesi Programı (KKYDP), ulusal kaynaklarla yürütülen destekleme faaliyetleri içerisinde kırsal kalkınma amaçlı tarımsal destekler içerisinde bulunmaktadır (Çobanoğlu ve ark., 2017). Kırsal kalkınma projelerini diğer projelerden farklı kılan özelliği, kırsal alt yapının iyileştirilmesinin yanı sıra üretim kaynaklarını en iyi şekilde değerlendirerek, bitkisel ve hayvansal üretimi artırmayı ve diğer gelir getirici çözümler geliştirmeyi bir arada ele alan, çok amaçlı entegre projeler olmasıdır (Can, 2007). Bu grupta bulunan proje destek konuları; ekonomik faaliyetlerin desteklenmesi ile modern sulamaya ilişkin makine ve ekipman desteği ile tarımsal üretim alt yapısının modernizasyonuna ilişkin makine ve ekipman destekleridir (Demirbük, 2013; Çobanoğlu ve ark., 2017a; Çobanoğlu ve ark., 2017).

KKYDP kapsamında Makine ve Ekipman Alımlarının Desteklenmesi Programı, kırsal alanda belirlenen bazı tarımsal makine ve ekipman alımlarına yönelik yapılacak harcamaları belirli oranlarda hibe olarak finanse etme yoluyla desteklemeyi hedeflemiştir. Bu yolla tarım sektörünün ihtiyaç duyduğu tarım alet ve makine altyapısı yönünden güçlendirmek, gelir ve sosyal standartlarını geliştirmek, tarımsal faaliyetler için geliştirilen yeni teknolojilerin üreticiler tarafından kullanımını yaygınlaştırarak daha kaliteli ve pazar isteklerine uygun üretim yapılmasını sağlamak, zor koşullarda ve bedenen çalışan üreticilerin işlerini kolaylaştırmak, üretim maliyetlerini düşürerek uluslararası düzeyde rekabet edebilir bir düzeye getirmek amaçlanmıştır (Anonim, 2010). Teklif çağrısı usulü ile yürütülen ve $\% 50$ hibe desteği sağlanan projeler, kır ve kent ayrımı yapılmaksızın ülke genelinde uygulanmaktadır.

2007 yılında başlatılan Makine Ekipman Alımlarının Desteklenmesi Programı (MEADP) kapsamında 2014 yılına kadar 51 çeşit makine ekipmandan oluşan toplam 270.044 adet makine ekipman alımı desteklenmiş ve bu makine-ekipmanlara toplam 1.212.225.834 TL hibe desteği verilmiştir. MEADP kapsamında desteklenen makine ve ekipman sayısı İzmir ilinde 2803 adet, Kemalpaşa İlçesinde ise 245 adet olarak belirlenmiştir. Türkiye'de desteklenen makine ve ekipmanlar içerisinde toplam 45.808 adet proje ile ilk sırada el traktörü ve ekipmanlarının desteklendiği belirlenmiştir. İzmir ilinde 513 adet, Kemalpaşa ilçesinde ise 96 adet ile en çok desteklenen makineekipmanın pülverizatör olduğu belirlenmiştir (Doğan, 2016).

2014 yılı sonrası durum değerlendirildiğinde ise; " Makine Ekipman Alımlarının Desteklenmesi Programı" adı altında bir tebliğ yayınlanmadığı belirlenmiştir. Ancak Kırsal Kalkınma Yatırımlarının Desteklenmesi Programının alt dalı olan Ekonomik Yatırımların Desteklenmesi Programı proje alt başlıkları incelendiğinde 
"Çiftlik Faaliyetlerinin Geliştirilmesine Yönelik Alt Yapı Sistemleri” başlığı altında çeşitli makine ve ekipmanların desteklendiği belirlenmiştir. Çiftlik faaliyetlerinin geliştirilmesine yönelik altyapı sistemleri başlığı altında listelenmiş makine-ekipmanlar maddeler halinde aşağıda gösterilmiştir:

i- Balıkçı barınaklarının modernizasyonu, balıkçı barınakları ile birlikte iç sularda, denizlerde ve havuzlarda yetiştiricilik yapan işletmeler için buzlama makinesi, balık nakil tankı (Balık nakil tankı üretimi ile orantılı olmalı), kafes ve kafes ağı, balık boylama makinası, balık pompası, tambur filtre, tekne üzerinde hidrolik yükleme ve boşaltma aparatı.

ii- Çiftlik gübresi depolama ve/veya işleme ve dağıtma sistemleri, çiftlik gübresi depolama ve/veya işleme tesisi olanlara çiftlik gübresi dağıtma sistemleri, ceviz hasat makinesi, silaj ve balya makinesi.

iii- Yaylacılar ve gezginci arıcılar için çekilir tip güneş paneli, çekilir tip karavan, yaylacılar için çadır ahır ve ağıl, gezginci arıcılar için bal süzme, sır alma, bal dinlendirme.

iv- Bitkisel üretime yönelik yüksek plastik tünel, meyve bahçelerinde don ve dolu zararını engellemeye yönelik sistemler, mantar yetiştiriciliğine yönelik sera, faal durumda olup yenilenebilir enerji kullanacak seraların modernizasyonu için ısıtma sistemi, 1sı perdesi, PE sera örtüsü (naylon) hariç diğer sera örtü çeşitleri.

v- Tarımsal üretimiyle orantılı çiftlik içinde üretilen ürünlerin işlenmesine yönelik işleme tesisleri, soğuk hava deposu, soğuk oda, şoklama ünitesi, çelik silo,

vi- Hayvansal üretime yönelik en fazla 1000 adet kapasiteli taşınabilir kanatlı kümesi, süt soğutma tankları, süt sağım sistemleri, yem karma (sabit/hareketli), yem kırma/ezme, büyükbaş yemlik ve suluk küçükbaş yemlik ve suluk, hayvan padok sistemleri, üstü kapalı kaba yem deposu (Anonim, 2017)

2006-2018 yılları arasında Çiftlik Faaliyetlerinin Geliştirilmesine Yönelik Altyapı Sistemleri Projesi ile hibe almaya hak kazanan İzmir ilinde toplam 26 işletme, Kemalpaşa ilçesinde ise sadece 1 işletme olduğu belirlenmiştir (Anonim, 2019a; Anonim, 2019b). Meyve bahçelerinde don ve dolu zararını engellemeye yönelik sistemlerin kurulması üreticilerin riskten korunma stratejilerinden bazılarıdır. Bu sistemlerin desteklenmesi üretimde verimlilik ve kalite artışının sağlanması bakımından oldukça önemlidir. Ayrıca üreticiler bu tip sistemleri kurarak tarım sigortası prim indirimlerinden de faydalanabilmektedirler. Bu kapsamda verilen hibe desteklerinin arttırılarak devam ettirilmesi üretim, verim artışının yanında istihdam kapasitelerinin artışı, toprak ve su kaynaklarının sürdürülebilir kullanımı açısından da son derece önemlidir.

Bu araştırmada; İzmir ili Kemalpaşa İlçesinde kiraz üretimi yapan işletmelerin KKYDP'nın alt programı olan Makine ve Ekipman Alımlarının Desteklenmesi Programından (MEADP) yararlanma durumlarının belirlenmesi ve bu yatırım desteğinden yararlanma eğilimlerini etkileyen faktörlerin ortaya konulması amaçlanmıştır.

\section{Materyal ve Metot}

Çalışmanın ana materyalini, İzmir İli Kemalpaşa İlçe Tarım ve Orman Müdürlüğü Çiftçi Kayıt Sistemine (ÇKS) dahil olan kiraz üreticilerinden (KKYDP'den yararlanan ve KKYDP'den yararlanmayan) 2015 üretim dönemine ait anket yoluyla elde edilen veriler oluşturmaktadır. Yapılan ön çalışmada 2015 yılı itibariyle ÇKS'ye kayıtlı kiraz işletmelerinin toplam sayısının 2400 olduğu belirlenmiştir. Ancak çalışmada tek bir ana kitle yerine KKYDP desteğinden yararlanan ve yararlanmayan işletmeler olarak iki ana kitle grubu üzerinden çalışma kapsamına girecek işletmeler belirlenmiştir. Kemalpaşa İlçesinde 2007-2014 yılları arası KKYDP Makine ve Ekipman desteklerinden yararlanan işletme sayısı 231'dir. Bu sayı KKYDP'den yararlanan işletmelerin ana kitlesini oluşturmaktadır. Bu işletmelerde anket yapılacak üreticilerin sayısının belirlenmesinde oransal örnek hacminde eşitlik 1 kullanılmıştır (Newbold, 1995).

$$
n=\frac{N p(1-p)}{(N-1) \sigma_{p x}{ }^{2}+p(1-p)}
$$

Eşitlikde;

$\mathrm{n}=$ Örnek hacmi; $\mathrm{N}=$ Toplam üretici sayısı ; $\mathrm{p}=$ Örneğe girecek üreticilerin oranı ve $\sigma^{2} \mathrm{px}=$ Oranın varyansıdır 
Güven aralığ $\% 90$ ve hata payı $\% 10$ kabul edilip, $\mathrm{p}=0.50,(1-\mathrm{p})=0.50$ dikkate alınarak örneğe girecek işletme sayısı 65 işletme olarak belirlenmiştir. KKYDP' den yararlanmayan işletmelerin ana kitlesi ise 2169 olarak belirlenmiştir. Yine oransal örnek hacmi formülü kullanılarak örneğe girecek işletme 52 işletme olarak belirlenmiştir. Böylece anket uygulanan toplam işletme sayısı 117 olarak belirlenmiştir. Bu işletme sahiplerinden anket yoluyla elde edilen birincil veriler öncelikle bilgisayar ortamına aktarılmış, KKYDP'den yararlanan ve KKYDP'den yararlanmayan işletmeler olarak sınıflandırılmıştır. Çalışmanın genel sonuçlarının analizi için ortalama ve yüzde hesapları ile çapraz tablolar ve frekans dağılımlarından yararlanılmıştır. Temel tanımlayıcı istatistiklerin yanı sıra teknik ve ekonomik verilere ilişkin değişkenlerin grup karşılaştırmaları için normal dağılışa uygunluğu Kolmogrov-Simirnov testi ile belirlendikten sonra normal dağılış gösteren değişkenler için $t$ testi yapılmıştır. Normal dağılış göstermeyen değişkenler için ise, işletme büyüklük grupları arasındaki karşılaştırmada Kruskal-Wallis testi, KKYDP makine-ekipman desteklerinden yararlanan ve yararlanmayan gruplar arasındaki karşılaştırmada Mann Whitney-U testi gibi parametrik olmayan testlerden faydalanılmıştır. Çalışmanın son bölümünde kiraz işletmelerinde KKYDP' den yararlanma durumuna etki eden faktörleri belirlemek amacıyla 0-1 modeli olarak da adlandırılan Logit modeli kullanılmıştır.

Modelde bağımlı değişken iki değer alıyorsa, bağımlı değişkenler tercih belirtmekte ve bu tür modeller ikili tercih modelleri olarak belirtilmektedir. Bu durumda olayın varlığı için 1, yokluğu için 0 kullanılmaktadır. Logit modelin parametrelerini tahmin için Gretl programı kullanılmıştır. Bu modelde bağımlı değişken (kukla değişken) Y olarak sembolize edilmiş, KKYDP' den yararlanan=1 ve yararlanmayan=0 alınmıştır.

$Y=\left\{\begin{array}{l}0 \text { KKYDP kapsamında MEADP 'den yararlanmayan işletmeler } \\ 1 \text { KKYDP kapsamında MEADP 'den yararlanan işletmeler }\end{array}\right.$

Bağımsız değişkenler olarak da kiraz üreticisinin yaşı, eğitim süresi, kiraz üretimindeki deneyim süresi, kiraz işletmesinin büyüklüğü, Kemalpaşa Kiraz Üreticileri Birliğine üye olup olmama durumu, kiraz yetiştiriciliğinde ihtisaslaşma durumu, brüt kar, net kar değişkenleri dikkate alınmıştır.

\section{Araştırma Sonuçları ve Tartışma}

\subsection{Araștırma kapsamındaki işletmelerin sosyo-ekonomik özellikleri}

Araştırma kapsamında ele alınan işletmelerde üretici yaşı, eğitim durumu, ailedeki birey sayısı, tarımsal deneyim süresi ve kiraz üretimi deneyimi süresi Tablo 1'de verilmiştir. İncelenen işletmelerde I. grup ve II. grupta ortalama üretici yaşı sırasıyla; 55.21 ve 53.09 iken, genel ortalamaya göre üretici yaşı 54.27 yıldır. İşletme gruplarına göre kiraz üretiminde deneyim süresi incelendiğinde, I. grup işletmelerde 29,55 yıl, II. grup işletmelerde 29.27 yıl ve genel ortalama olarak 29.43 yıl olarak bulunmuştur. Her iki gruptaki üreticilerin deneyim sürelerinin birbirine yakın değerde olduğu görülmektedir. Mann-Whitney U testi sonuçlarına göre; gerek tarımsal üretimde deneyim süresi ortalamaları bakımından (Mann-Whitney $U=1478,000, p=0,241$ ) gerekse kiraz üretiminde deneyim süresi ortalamaları bakımından (Mann-Whitney $U=1601,000 p=0,615$ ) gruplar arasındaki farkl11ık istatistik olarak anlamlı bulunmamıştır.

İncelenen işletmelerde üretim desenine bakıldığında, işletmelerin genelinde kiraz alanlarının önemli bir paya sahip olduğu görülmektedir. İşletmelerin tüm üretim alanı içerisindeki kiraz üretim alanı payları KKYDP'den yararlanan işletmelerde \%56.98, KKYDP'den yararlanmayan işletmelerde $\% 59.32$ olarak belirlenmiştir. KKYDP'den yararlanmayan işletmelerin kiraz üretiminde daha fazla uzmanlaşmış olduğu belirlenmiştir. Genel olarak bakıldığında incelenen işletmelerde üretim alanının \%58'ini kiraz oluşturmaktadır. Gruplar bazında bakıldığında KKYDP'den yararlanan işletmeler \%56.98'lik payla ortalama 18 dekar alanda, destekten yararlanmayan işletmelerin ise \%59.32'lik payla ortalama yine yaklaşı 19 dekar alanda kiraz üretimi yaptığ 1 saptanmıştır.

KKYDP alt programı MEADP'den yararlanan işletmelerde brüt kar 6053,40 TL/da iken, destekten yararlanmayan işletmelerde dekara 6654,98 TL' dir. Buna göre KKYDP' dan yararlanan işletmelerde net kar $4626,74 \mathrm{TL} / \mathrm{da}$ destekten yararlanmayan işletmelerde ise 5249,75 TL/da olarak belirlenmiştir. Destekten yararlanmayan işletmelerde brüt karın ve net karın daha yüksek belirlenmesinin nedeni, destekten yararlanmayan 
işletmelerde ağaç başına verimin ve kiraz satış fiyatlarının destekten yararlanan işletmelere göre daha yüksek olması ve kiraz üretiminde daha fazla uzmanlaşmış olması ile açıklanabilmektedir.

\section{Tablo 1. Kiraz üretimi yapan üreticilerin ve işletmelerin bazı özellikleri}

Table 1. Some features of cherry producers and farms

\begin{tabular}{llll}
\hline & \multicolumn{2}{c}{ İşletme Grupları } \\
\cline { 2 - 3 } Özellikler & $\begin{array}{l}\text { I.Grup KKYDP'den } \\
\text { yararlanan }\end{array}$ & $\begin{array}{l}\text { II.Grup } \\
\text { KKYDP'den } \\
\text { yararlanmayan }\end{array}$ & $\begin{array}{l}\text { Işletmeler } \\
\text { Ortalaması }\end{array}$ \\
\hline Üreticinin Yaşı & 55.21 & 53.09 & 54.27 \\
Eğitim Durumu (Yıl) & 7.26 & 7.01 & 7.13 \\
Ailedeki Birey Sayısı & 3.96 & 3.80 & 3.89 \\
Tarımsal Deneyim Süresi & 34.82 & 33.75 & 34.34 \\
Kiraz Üretiminde Deneyim Süresi & 29.55 & 29.27 & 29.43 \\
Kiraz Arazisi Büyüklüğ̈̈(da) & 17.91 & 18.96 & 18.38 \\
Uzmanlaşma (İhtisaslaşma) Oranı (\%) & 56.98 & 59.32 & 58.06 \\
Kiraz Üretim Dalında Brüt Kar (TL/da) & 6053.4 & 6654.98 & 6354.19 \\
Kiraz Üretim Dalında Net Kar (TL/da) & 4626.74 & 5249.75 & 4938.24 \\
\hline
\end{tabular}

\section{2. Üreticinin örgütlenme durumu}

Üreticilerin tarımsal girdi sağlama, teknik danışmanlık ve pazarlardaki risk ve belirsizlikleri azaltma konularındaki beklentilerini karşılamak üzere örgütlenmeye ihtiyaçları bulunmaktadır. Örgütlenme, üreticilere elde edilen tarımsal katma değerden daha fazla pay almaları, tarımsal girdilerin maliyetlerini azaltma, daha iyi ürün fiyatı sağlama, teknik bilgi edinmede kolaylık ve pazarlık gücü sağlama, ölçek ekonomisine ulaşma, ürün farklılaşması, fiyatların oluşumuna katkı sağlama gibi konularda değişik avantajlar sağlamaktadır. Gelişmiş ülkelerin ekonomik ve sosyal yaşamının gelişiminde özel sektör ve kamu sektörü yanında kooperatifçilik üçüncü sektör olarak ortaya çıkmış olup, ortakların belirli bir amaç için örgütlenmelerini sağlamada kullanılan en yaygın modeldir (Sayın ve Sayın 2004; Çıkın, 2016).

İncelenen işletmelerde her iki gruptaki üreticilerin tamamının (117 Üretici) Ziraat Odasına üye olduğu belirlenmiştir. KKYDP'den yararlanan üreticilerin \%33.85'inin Kemalpaşa Kiraz Üreticileri Birliğine üye iken, yararlanmayan üreticilerin \%80.77'sinin Kemalpaşa Kiraz Üreticileri Birliğine üye olduğu belirlenmiştir. Bunun dışında üreticilerin \%12.82'sinin Tarım Kredi Kooperatiflerine ve \%46.15'inin Sulama Kooperatiflerine de ortak oldukları da görülmektedir (Tablo 2).

\section{Tablo 2. Incelenen işletmelerde üreticilerin örgütlenme durumlart}

Table 2. Cooperation status of producers in investigated farms

\begin{tabular}{lrrrrrrr}
\hline & \multicolumn{2}{c}{$\begin{array}{c}\text { KKYDP'den } \\
\text { Ortaklık/Üyelik }\end{array}$} & \multicolumn{2}{c}{$\begin{array}{c}\text { KKYDP'den } \\
\text { yararlanman }\end{array}$} & \multicolumn{2}{c}{ Genel } \\
\cline { 2 - 9 } & Sayı & \multicolumn{2}{c}{$\%$} & Sayı & $\%$ & Sayı & $\%$ \\
& & & & & & & \\
\hline Ziraat Odası & 65 & 100.00 & 52 & 100.00 & 117 & 100.00 \\
Kemalpaşa KÜB & 22 & 33.85 & 42 & 80.77 & 64 & 54.70 \\
Tarım Kredi Koop. & 8 & 12.31 & 7 & 13.46 & 15 & 12.82 \\
Sulama Koop. & 36 & 55.38 & 18 & 34.62 & 54 & 46.15
\end{tabular}




\subsection{Kiraz işletmelerinde üreticilerin KKYDP kapsamındaki makine ekipman yatırım desteğinden yararlanma ĕgilimini etkileyen faktörler}

$\mathrm{Bu}$ bölüm altında, kiraz üreticilerinin yatırım yapmaya istekli olup-olmama durumlarına diğer bir ifade ile KKYDP kapsamında makine ve ekipman yatırımı yapıp-yapmama durumlarına etki eden değişkenleri belirleyebilmek için logit modeli kullanılmıştır.

Modelde bağımlı değişken olarak KKYDP' den yararlanan veya KKYDP' den yararlanmayan üretici teması temel alınmıştır. Eğer KKYDP' den yararlanmışsa 1, yararlanmamışsa 0 kukla değişkeni kullanılmıştır.

Logit Modelin bağımsız değişkenleri olarak; kiraz üreticisinin yaşı, eğitim süresi, kiraz üretimindeki deneyim süresi, kiraz işletmesinin büyüklügü, Kemalpaşa Kiraz Üreticileri Birliğine üye olup olmama durumu, kiraz yetiştiriciliğinde uzmanlaşma durumu, brüt kar ve net kar gibi değişkenler dikkate alınmıştır.

Modelin değerlendirilmesi aşamasında ilk olarak likelihood ratio test (Chi-square) değerinin sonucuna bakılmıştır. Modelde; $p$ değeri $=0.0000<0.01$ olduğu için seçilmiş olan bağımsız değişkenlerin, bağımlı değiş̧eni açılayabildiğini göstermektedir.

Tablo 3' de verilen modelin sonuçlarına göre, üreticilerin KKYDP' den yararlanma durumu üzerine, üretici yaşı, eğitim süresi, kiraz üretimindeki deneyim süresi, Kemalpaşa Kiraz Üreticileri Birliğine üye olup olmama durumu, kiraz yetiştiriciliğinde uzmanlaşma durumu, brüt kar gibi değişkenlerin etkisinin istatistiksel olarak önemli olduğu belirlenmiştir. Diğer taraftan KKYDP kapsamında alet-makine yatırım desteğine yönelme üzerinde işletme büyüklüğü ve kiraz arazisi büyüklüğünün etkisinin olmadığı görülmektedir.

\section{Tablo 3. KKYDP makine ekipman yatırımlarının desteklenmesi programı kapsaminda verilen hibe desteğinden üreticilerin yararlanma eğilimini etkileyen faktörler (logit modeli sonuçları)}

Table 3. Factors of effecting the investment utilization perceptions of the producers within RDISP Support Scheme for the Purchase of Agricultural Machines and Equipment (Logit Model Results)

\begin{tabular}{lll}
\hline \begin{tabular}{c} 
Bağımlı Değişken: Üreticinin KKYDP' den Yararlanıp Yararlanmama \\
Durumu \\
\multicolumn{2}{c}{ Yararlanma (1), Yararlanmama (0) }
\end{tabular} \\
\hline Bağımsız Değişkenler & Katsayı & \\
\hline Sabit & $1.26662^{* * *}$ & Değişkenlerin Marjinal Etkileri \\
Üreticinin Yaşı & $-0.119397^{* * *}$ & $0.0016^{* * *}$ \\
Eğitim Seviyesi & $1.17121^{*}$ & $0.0539^{*}$ \\
Kiraz Üretiminde Uzmanlaşma & $1.37847^{*}$ & $0.0548^{*}$ \\
Brüt kar & $1.02292^{* *}$ & $0.0496^{* *}$ \\
Kiraz Üreticileri Birliğine Üyelik & $2.15771^{* * *}$ & $0.0001^{* * *}$ \\
Kiraz Yetiştiriciliği Deneyimi & $0.18754^{* * *}$ & $0.0002^{* * *}$ \\
İşletme Büyüklüğ̈̈ & 0.01201 & 0.4732 \\
Kiraz Arazisi Büyüklüğü & -0.0390741 & 0.1829 \\
LR Chi2(8)=59,2496 & Log Likelihood $=-50.85055$ & $\mathrm{R}^{2}=0.414331$ \\
\hline
\end{tabular}

$\left({ }^{*}, * *, * * *\right.$ sırasıyla $0.10,0.05,0.01$ istatistiki anlamll1ı̆̆ göstermektedir.)

Üreticilerin KKYDP'den yararlanma isteği ile üreticilerin yaşı arasında negatif yönlü bir ilişki mevcuttur. Üreticilerin yaşı arttıkça destekten yararlanma eğilimleri azalış göstermektedir. Diğer bir ifade ile genç üreticilerin destekten yararlanma eğilimlerinin yüksek olduğu söylenebilir. Bu ilişki istatistik açıdan anlamlıdır.

KKYDP'den yararlanma isteği ile üreticilerin eğitim seviyesi arasında pozitif yönlü bir ilişki bulunmaktadır. Üreticinin eğitim seviyesi yükseldikçe destekten yararlanma eğilimleri artmaktadır. İncelenen işletmelerdeki genç üreticilerin eğitim seviyeleri orta yaş ve üzeri üreticilere oranla daha yüksektir. Bu da üreticinin yaşı arttıkça yararlanma eğiliminin azalış gösterdiği sonucunu desteklemektedir. Bu ilişki istatistik açıdan anlamlıdır.

KKYDP'den yararlanma isteği ile üreticilerin kiraz üretiminde ihtisaslaşma durumu arasında pozitif yönlü bir ilişki bulunmuştur. Üreticilerin tarımda uzmanlaşma oranı arttıkça destekten yararlanma eğilimleri artış göstermektedir. Bu ilişki istatistik açıdan da anlamlıdır. 
KKYDP'den yararlanma isteği ile üreticilerin elde ettikleri dekara brüt kar arasında pozitif yönlü bir iliş̧ki mevcuttur. İşletmelerde dekara elde edilen brüt kar arttıkça, üreticilerin destekten yararlanma eğilimleri artış göstermektedir. Bu ilişki de istatistik açıdan anlamlıdır.

KKYDP'den yararlanma isteği ile üreticilerin Kiraz Üreticileri Birliğine üye olmaları arasında pozitif yönlü bir ilişki bulunmuştur. Kiraz Üreticileri Birliğine Üye olan üreticilerin diğer üreticilere göre destekten yararlanma isteği daha fazladır. Bu iliş̧i istatistik açıdan anlamlı bulunmuştur.

KKYDP' den yararlanma isteği ile üreticilerin kiraz yetiştiriciliği deneyimleri arasında pozitif yönlü bir ilişki bulunmuştur. Kiraz yetiştiriciliği konusunda deneyim süresi yükseldikçe destekten yararlanma isteği artmaktadır. Bu ilişki istatistik açıdan anlamlı bulunmuştur.

\section{Sonuç}

$\mathrm{Bu}$ çalı̧̧mada KKYDP kapsamında, İzmir ili Kemalpaşa ilçesinde uygulanmış olan Makine ve Ekipman Alımlarının Desteklenmesi Programından (MEADP) yöredeki kiraz üretimi yapan işletmelerin yararlanma eğilimleri belirlenmiş ve desteğin devamlılığı tartışılmıştır.

Çalışmada Logit Model Sonuçlarına göre; üreticilerin KKYDP'den yararlanma isteği ile üreticilerin yaşı arasında negatif yönlü bir ilişki bulunmuştur. Üreticilerin yaşı arttıkça destekten yararlanma eğilimleri azalış göstermektedir. KKYDP'den yararlanma isteği ile üreticilerin eğitim düzeyi arasında pozitif yönlü bir ilişki bulunmuştur. Üreticilerin eğitim düzeyi yükseldikçe destekten yararlanma eğilimleri de artmaktadır.

KKYDP'den yararlanma isteği ile kiraz üretimindeki deneyim süresi, Kemalpaşa Kiraz Üreticileri Birliğine üye olup olmama durumu, kiraz yetiştiriciliğinde uzmanlaşma durumu, brüt kar gibi değişkenlerin de pozitif etkisinin olduğu belirlenmiştir. Üreticilerin yaşı, eğitim seviyesi, kiraz üretiminde uzmanlaşma durumu, brüt kar, Kiraz Üreticileri Birliğine üye olup olmama durumu ve kiraz yetiştiriciliğindeki deneyiminin istatistiksel olarak önemli olduğu belirlenmiştir. KKYDP'den yararlanan işletmelerin makine-ekipman alt yapısının güçlenmesiyle, iş yükünün azaldığı belirlenmiştir. 2015 yılı üretim döneminde üreticiler üretim maliyetlerinin azaldığını belirtmişlerdir.

2015 yılı ve sonrasında "Makine Ekipman Alimlarının Desteklenmesi Programı" adı altında bir tebliğ yayınlanmamış olup, ancak Kırsal Kalkınma Yatırımlarının Desteklenmesi Programının alt dalı olan Ekonomik Yatırımların Desteklenmesi Programı kapsamında "Çiftlik Faaliyetlerinin Geliştirilmesine Yönelik Alt Yapı Sistemleri” başlığı altında çeşitli makine ve ekipmanların desteklendiği belirlenmiştir.

Üreticinin uygun fiyata, teknolojisi ileri çeşitli makine ekipmana sahip olarak, kaliteli ürün elde etmesi, tarımsal üretimini ve gelirini artırması ve sektörün dinamik olabilmesi için bu programın devamlılığı son derece gereklidir. Ancak işletmeler için başvuru esnasında bürokratik engellerin ve istenen evrakların fazla olması sorun oluşturmaktadır. Proje ve teklif hazırlamada yardımcı olabilmek adına KKYDP projelerinde danışmanlık yapan işletmelerin danışmanlık ücretleri hibeden karşılanmalıdır. Bu öneriye alternatif olarak, Tarım ve Orman Bakanlı̆̆ 1 İl ve İlçe Müdürlüklerinde proje hazırlanması konusunda ayrı bir birim kurularak işletmelere hizmet verilmesi ve bu konuda farkındalığın artırılması de son derece önemlidir. 
Kaynakça

Anonim, (2010). 18.03.2010 Tarih 27525 Sayılı Resmi Gazete. Kırsal Kalkınma Yatırımlarının Desteklenmesi Tebliği.

Anonim, (2017). Kırsal Kalkınma Yatırımlarının Desteklenmesi Programı 12. Etap Tebliğ ve Uygulama Rehberi.

Anonim, (2019a). İzmir İl Gıda Tarım ve Hayvancılık Müdürlüğü Kırsal Kalkınma ve Örgütlenme Şube Müdürlüğü Verileri, İzmir.

Anonim, (2019b). Kemalpaşa İlçe Gıda Tarım ve Hayvancılık Müdürlüğü Kırsal Kalkınma ve Örgütlenme Şube Müdürlüğü Verileri, İzmir, Kemalpaşa.

Asoğlu, V., (2015), Kırsal Kalkınma Yatırımlarının Desteklenmesi Programından Faydalanan Işsletmelerin Ekonomik Analizi: ŞanlıurfaDiyarbakır Örneği, Doktora Tezi, Harran Üniversitesi Fen Bilimleri Enstitüsü, Şanlıurfa, 156s.

Asoğlu, V., Kaya, K., Sevinç, M., Sevinç, G., Şit, M., (2016). Kırsal Kalkınma Yatırımlarının Desteklenmesi Programının (KKYDP) Dünü Bugünü (2006-2015), XII. Ulusal Tarım Ekonomisi Kongresi, 25-27 Mayıs 2016, Isparta, s. 2089-2098

Beycan, H., (2009). Kırsal Kalkınma Yatırımlarının Desteklenmesi Programı ve Bu Çerçevede Proje Uygulama Örneği, Yüksek Lisans Tezi, Dumlupınar Üniversitesi Sosyal Bilimler Enstitüsü, Kütahya, 172s.

Can, M., (2007). AB Kırsal Kalkınma Programlarının Türkiye’nin Kırsal Kalkınması Açısından İncelenmesi- SAPARD ve IPARD Örneği, Yüksek Lisans Tezi, Gaziosmanpaşa Üniversitesi Fen Bilimleri Enstitüsü, Tokat, 155s.

Çıkın, A., (2016). Bir Başkadır Kooperatifçilik, S.S. Tariş Zeytin ve Zeytinyağı Tarım Satış Kooperatifleri Birliği, İzmir.

Çobanoğlu, F., Cankurt, M., Tunalığlu, R., Yılmaz, H. İ., Nalbantoğlu, A., (2017). Kırsal Kalkınma Yatırımlarının Desteklenmesi Programının Etkisinin Değerlendirilmesi: Bursa İli Örneği, Tekirdağ Ziraat Fakültesi Dergisi, 14(01): 16-27, Tekirdağ.

Çobanoğlu, F., Tunalığlu, R., Yılmaz, H. İ., Bozkıran S., Nalbantoğlu, A., Yıldız, H., (2017a). Kırsal Kalkınma Yatırımlarının Desteklenmesi Programının Etkisinin Değerlendirilmesi: Konya İli Örneği, Selçuk Tarım ve Gıda Bilimleri Dergisi, 31(1):16-25, Konya.

Demirbük, M., (2013). Kırsal Kalkınma Yatırımlarının Desteklenmesi Programının Değerlendirilmesi Sivas İli Örneği, Yüksek Lisans Tezi, Gaziosmanpaşa Üniversitesi Fen Bilimleri Enstitüsü, Tokat, 99s.

Doğan, B., (2016). Kırsal Kalkınma Yatırımlarının Desteklenmesi Programı Kapsamında Kiraz Işsletmelerinin Yatırımlardan Yararlanma Düzeyi ve İşletmelerin Yatırım Eğilimlerinin Belirlenmesi: Kemalpaşa İlçesi Örneği, Yüksek Lisans Tezi, Ege Üniversitesi, Fen Bilimleri Enstitüsü, $150 \mathrm{~s}$.

FAO, (2018). Birleşmiş Milletler Gıda ve Tarım Organizasyonu, (Erişim Tarihi: 1 Ekim 2020)

Newbold, P., (1995), Statistics for Business and Economics, Prentice Hall International, New Jersey.

Sayın, B. ve Sayın., (2004). Türkiye’de Tarımsal Üretici Örgütlenmesi, Avrupa Birliğine Uyum Hazırlıkları ve Tarımsal Üretici Birlikleri Kanunu. Türkiye VI. Tarım Ekonomisi Kongresi. 16-18 Eylül 2004. Tokat, 466-470s.

Soysal, D., (2018). Kirazda Yeni Terbiye Sistemleri Üzerine Araştırmalar, Doktora Tezi, Ondokuz Mayıs Üniversitesi, Fen Bilimleri Enstitüsü, Samsun.

Trade Map, (2019). Trade Statistics for International Business Development, http://www.trademap.org, (Erişim Tarihi: 6 Eylül 2020).

TUIK, (2019). Tarım İstatistikleri Verileri, Ankara, (Erişim Tarihi: 1 Ekim 2020). 